\title{
Do samba de roda ao rap: trânsitos musicais e marcadores sociais das diferenças em contextos de resistência de mulheres negras em Cachoeira/BA
}

From samba de roda to rap: musical transits and social markers of differences in contexts of black women resistance in Cachoeira, BA

Francimária Ribeiro Gomes ${ }^{1}$ Universidade Federal da Bahia franriberogomes@gmail.com 


\section{Resumo}

O artigo apresenta os contextos em torno dos processos de protagonismo de mutheres negras ligadas ao samba de roda e ao rap em Cachoeira, Recôncavo da Bahia. Marcadas por suas condições de gênero, raça/etnia e classe social, as interlocutoras têm suas trajetórias analisadas a partir do desenvolvimento da cidade desde o aporte teórico dos estudos da etnomusicologia, dos feminismos e dos estudos culturais. A metodologia é traçada a partir de um estudo etnográfico de caráter qualitativo, que tem como foco um estudo empírico baseado no diálogo da autora com as interlocutoras. Ela se sustenta a partir de uma pesquisa bibliográfica da história de Cachoeira, com o objetivo de traçar a importância das mulheres negras para o desenvolvimento da cidade, tendo o samba de roda como formador da identidade cultural diaspórica do Recôncavo. Por meio da Análise Crítica do Discurso das letras de músicas é possivel perceber os gêneros musicais em questão como elementos ligados à cultura popular em diferenciados aspectos geracionais e que podem se tornar potências de ação comunicacional por meio da produção de discursos contra-hegemônicos.

Palavras-chave: Mulheres negras. Música. Feminismos. Comunicação popular.

\section{Abstract}

This article presents the contexts surrounding the processes of black women protagonism related to samba de roda and rap in Cachoeira, Recôncavo of Bahia. Marked by their conditions of gender, race/ ethnicity and social class, the female interlocutors have their trajectories analyzed since the development of the city from the theoretical contribution of the ethnomusicology studies, feminisms and cultural studies. The methodology is drawn from an ethnographic study of qualitative nature, which focuses on an empirical study based on the author's dialogue with the interlocutors. It is based on a bibliographical research of the history of Cachoeira, with the aim of tracing the importance of black women for the development of the city, with the samba de roda as the formative of the diasporic cultural identity of the Reconcavo. Through the Critical Analysis of the Discourse of the song lyrics it is possible to perceive the musical genres in question as elements linked to popular culture in different generational aspects and that they can become powers of communicational action through the production of counter-hegemonic discourses.

Keywords: Black women. Music. Feminisms. Popular communication. 


\section{Introdução}

"A função da arte é fazer mais do que definir - é imaginar o que é possível". bell hooks ${ }^{2}$

O presente artigo apresenta aspectos da pesquisa de mestrado 3 por mim realizada que teve o objetivo de analisar como os processos de protagonismo de mulheres negras ligadas ao samba de soda e ao rap na cidade de Cachoeira, no Recôncavo da Bahia, têm suas experiências cotidianas mediadas pela música e como elas potencializam suas produções em instrumentos contra-hegemônicos de comunicação popular. Foram utilizados aportes teóricos dos campos dos estudos de gênero e feminismos, da etnomusicologia e da comunicação, ferramentas metodológicas, como o diário de campo, registros audiovisuais e sonoros, para subsidiar a análise das trajetórias das interlocutoras, que têm suas vivências atravessadas pelas relações de gênero, relações etnicorraciais, por questões geracionais e por relações de poder que marcam suas produções artísticas. Os registros coletados na pesquisa de campo aconteceram de junho de 2015 a setembro de 2016.

Minha relação com a temática de pesquisa que envolve a música, as relações de gênero e os estudos da comunicação surge desde a minha formação acadêmica em comunicação social. Enquanto militante da comunicação popular, pude refletir e perceber ao longo da minha caminhada profissional como a música adquire uma potência comunicacional quando articulada aos contextos sócio-históricos de suas produtoras. Essa articulação entre a cultura e a comunicação estabelece os espaços de resistência dos povos, que são vistos e tornados objetos pelos sistemas de opressão.

Em 2014 fui morar na cidade de Cachoeira e minha perspectiva se intensificou quando comecei a viver a cidade e conhecer suas moradoras, em sua grande maioria, mulheres negras e de cor, que na labuta diária se comunicavam através da música, de uma fala cantada, característica do sotaque baiano, ao diálogo entre as mais velhas, de vez em outra, um samba era puxado. Foi assim que conheci dona Dalva, dona Mariinha e tantas outras sambadeiras da cidade. Mulheres que com toda a sua sabedoria ancestral contavam suas histórias e tinham paciência em compartilhá-las com essa forasteira que aqui escreve.

\footnotetext{
20 pseudônimo bell hooks é como a escritora, ativista feminista antirracista e intelectual negra estadunidense Gloria Jean Watkins é mais conhecida. O pseudônimo é inspirado em sua avó Bell Blair Hooks, e sua escrita em letras minúsculas é uma reivindicação política da teórica para desafiar as normas e convenções acadêmicas e linguísticas, com o objetivo de questionar o foco dado mais à pessoa, e não ao conteúdo por ela elaborado.

3 O mestrado foi defendido em agosto de 2017 e possui uma análise sociológica e comunicacional da música como mediadora das relações cotidianas das interlocutoras participantes da pesquisa. Assim, os aportes da etnomusicologia e da musicologia utilizados como referência no trabalho vem para dar suporte à compreensão da música como conteúdo mediador das relações de gênero, raça e de poder que marcam as trajetórias das já citadas interlocutoras.
} 
Aprendi muito ao longo dos anos morando na cidade, sobretudo, a me reconhecer diante dos marcadores que carrego e que moldam o meu ser e estar no mundo social: mulher cisgênera, de cor, que assim como elas, tem sua história marcada e herdada pela colonização do território brasileiro, da cultura ancestral e de nossas subjetividades. Essas compreensões que surgiram da afetação do meu eu pesquisadora com a moradora e o campo de investigação, me fizeram identificar que a melhor metodologia de análise seria a observação participante. Estabeleci vínculos que transformaram minha vida e que me fizeram identificar na história das mulheres interlocutoras da dissertação os nossos pontos de vista em comum - standup pointview- (Patricia Hill Collins, 2012), marcados pelas relações de poder socioestruturantes: o patriarcado, o racismo e o capitalismo. Assim, esse trabalho, desde uma perspectiva feminista, é a reivindicação de uma reescrita da história conhecida da cidade de Cachoeira, mas dessa vez, contadas pelas próprias interlocutoras a partir de suas experiências mediadas pela música.

A primeira das interlocutoras da pesquisa é dona Dalva Damiana de Freitas, 90 anos, doutora Honoris Causa do Samba de Roda do Recôncavo Baiano. Ex-charuteira, é cantora e compositora, membra da Irmandade de Nossa Senhora da Boa Morte e um dos nomes mais importantes da cultura popular negra do país. Descendente de negras escravizadas, dona Dalva tem uma trajetória marcada pela resistência e pelo enfrentamento a uma sociedade racista e desigual. Como agitadora cultural, começou o grupo de Samba de Roda Suerdieck ${ }^{4}$, em 1961, durante os intervalos do trabalho na charutaria que deu o nome ao grupo junto a colegas de trabalho.

A partir dali sua vida foi dedicada à cultura popular, à cultura de seu povo. Além do grupo, dona Dalva constituiu seu legado em ações por meio da Associação Cultural Dalva Damiana de Freitas e da Casa do Samba de Roda de Dona Dalva ${ }^{5}$. Na Casa do Samba acontece a execução de projetos culturais voltados à comunidade de Cachoeira. Dentre eles está a continuidade da tradição por meio do samba de roda mirim Flor do Dia.

Um dos grupos mais antigos e importantes para a história do gênero musical, o Samba de Roda Suerdieck possui um corpo de sambadeiras que se apresentam vestidas com indumentárias de baiana e um corpo de tocadores. A estética marcada pela vestimenta, bem como a tradição que o grupo carrega nas letras e no fazer musical, remetem ao samba de roda da origem, surgido das comunidades negras do recôncavo como forma de resistência cultural.

\footnotetext{
$4 \quad$ Fundado em 1961, o Samba de Roda Suerdieck recebe esse nome por ter surgido no interior da fábrica de charutos da filial na cidade de Cachoeira. No intervalo dos trabalhos ou no fim do expediente, dona Dalva se reunia com colegas para participar de novenas e tocadas em eventos religiosos. Por serem todas do mesmo local de trabalho elas ensaiavam escondidas até serem descobertas pela gerência. Em um acordo firmado entre as sambadeiras e a chefia elas passaram a ter meia hora do expediente para ensaiar sem que isso fosse descontado de seus salários, em troca, o grupo recebeu o nome da charutaria (MARQUES, 2003, p. 187).

5 A Casa do Samba de Roda de Dona Dalva surge como um dos projetos de desenvolvimento e salvaguarda da memória de manifestações culturais e religiosas de Cachoeira e do Recôncavo através da Associação Cultural do Samba de Roda Dalva Damiana de Freitas, quando instituída em 2002. A partir disso a Casa do Samba de Dona Dalva começou seus trabalhos que valorizavam a arte, a cultura e a educação junto à sede do Laboratório de Etnomusicologia, Antropologia e Audiovisual (LEAA/Recôncavo), entidade parceira do Samba de Dona Dalva. Só em 22 de novembro de 2009 que a Casa do Samba consegue uma sede própria, a casa amarela de número 19 na rua Ana Néri, no centro de Cachoeira. Na sede, que era mantida por meio de um convênio com a prefeitura de Cachoeira para o financiamento do aluguel do espaço, são realizadas rodas de samba, palestras, cursos e a execução de projetos de música, dança, desenho e artesanato, abertos para toda a comunidade de Cachoeira e região, sobretudo crianças, jovens e mulheres.
} 
É também do grupo a segunda interlocutora da pesquisa, dona Maria Lúcia de Araújo, 70 anos, a dona Mariinha. Ex-operária das indústrias fumageiras da região, dona Mariinha é um dos principais nomes quando se pensa do samba Suerdieck. Conheceu dona Dalva na charutaria e lá entrou no grupo. Após um breve afastamento por dificuldades familiares, retornou ao samba de onde não pretende sair mais. Exímia sambadeira é com destreza que ela desliza sobre o palco nas apresentações do grupo. Assim como dona Dalva, é descendente de negras escravizadas.

MC Jayne, a terceira interlocutora, começou sua carreira artística também através do samba de roda, como integrante do grupo de samba de roda mirim Flor do Dia. Contudo, sua aproximação com o hip hop por meio das aulas de dança em outro projeto social na cidade a fez migrar inteiramente para o rap. Atualmente segue em ascensão como um dos principais nomes da cena do rap do interior e referência do rap feito por mulheres no território baiano.

Três mulheres negras de diferentes gerações que têm suas trajetórias atravessadas por experiências marcadas por seus corpos racializados, suas condições de gênero e de classe social. Essas interseccionalidades, fundamentais para a leitura de seus protagonismos, em seus discursos cotidianos e em suas produções musicais e artísticas, são também importantes para entender em quais medidas suas trajetórias se aproximam e se afastam a partir de suas experiências individuais e coletivas e, como a cultura da diáspora no recôncavo segue em retroalimentação (GOMES, 2017).

Enquanto ciência, a música se formata a partir de aspectos mnemônicos ou repetitivos da memória para transmitir por meio dos mais variados sons as relações cotidianas, sendo ainda responsável pela possibilidade de criação e de recriação da vida em sociedade através da cultura e da comunicação. A música, assim como a cultura, como explicam as etnomusicólogas Angela Lühning e Laila Rosa (2010, p.319-20), "continua apenas como uma das várias expressões artísticas ou estéticas, um entretenimento ou então, um negócio lucrativo. Essa situação impede que a música seja percebida como forma complexa de expressão cultural identitária".

Enquanto meio que possibilita o entendimento da estrutura social, a música é canal de expressão de subjetividades, de identidades compartilhadas através da representação de grupos sociais, e ainda produz materialidade (MOREIRA, 2013). Assim, ela possibilita "refletir, reforçar ou contestar determinados comportamentos culturais e instituições sociais" (DINIZ, 2010, p.20). Fluida e não fixa, da mesma maneira que os sujeitos que por ela constroem suas trajetórias, a música amplia o campo de possibilidades justamente por sua característica polissêmica.

Campo a cada dia mais emergente e urgente de contextualização teórica, a relação entre gênero e música é o principal mote dessa pesquisa. Relacionar as vivências e experiências de dona Dalva, dona Mariinha e MC Jayne é também visibilizar a história das mulheres negras, que têm suas trajetórias e produções artísticas negadas. Além disso, ao entrelaçar ainda suas produções como possibilidades de comunicação popular, o objetivo é trazer dentro do campo da música e das relações de gênero essa tríade como potência de transformação. 
Para abordar as perspectivas das três interlocutoras, são usados o conceito do ponto de vista comum, o standup pointview(COLLINS, 2012) do feminismo negro. A partir de experiências comuns de racismo, as histórias das mulheres negras se aproximam, mesmo que essas experiências não sejam as mesmas, já que a própria categoria de mulheres negras é heterogênea (WERNECK, 2010; CARDOSO, 2012). É a partir do entendimento da fluidez das experiências das interlocutoras, que apresentam diferentes experiências marcadas pela idade/geração que o Samba de Roda e o Rap se aproximam enquanto elementos culturais diaspóricos. Para isso usa-se a categoria trânsito musical, que se insere no contexto da pesquisa a partir desse viés (GOMES, 2017).

O conceito foi trabalhado pela etnomusicóloga Flávia Diniz (2010) em sua pesquisa sobre os trânsitos entre a capoeira Angola, o candomblé e o samba de roda. No trabalho a pesquisadora mostra, ancorada em referenciais teóricos da etnomusicologia, como elementos, traços e características de um denominador cultural comum, no caso a cultura afro-brasileira, coexistem nas três manifestações. Estas que se estruturaram a partir de contextos de resistência, de afirmação e dos diferentes fluxos diaspóricos que reinscrevem costumes e características da cultura de matriz africana no contexto brasileiro. A capoeira Angola e o samba de roda apresentam músicas, toques e cantigas vindas e manifestadas no candomblé por meio de um empréstimo musical.

Ou seja, trânsito musical é a recorrência de "parâmetros musicais", [...]determinados ritmos, linhas melódicas, textos de cantigas, timbres vocais, instrumentos musicais, texturas, procedimentos rituais, gestos, conceitos e comportamentos - em diferentes formas expressivas ou estilos musicais. Esta recorrência pode ser fruto da difusão por contato ou migração, de empréstimos e adaptações mútuos ou da origem em uma matriz comum. Preferi o termo trânsito musical por considerá-lo mais dinâmico, dando a ideia de fluxo constante em muitas direções (DINIZ, 2010, p. 89, grifos da autora).

A partir do conceito de trânsito musical, passa a ser possível assimilar como as distintas gerações representadas pelas interlocutoras, bem como suas trajetórias permeadas pela música, se configuram. Enquanto dona Dalva Damiana, 90 anos, cantora, compositora, sambadeira transparece sua vivência em suas composições de samba de roda, paixão que dedicou toda sua vida, os 20 anos de diferença que a separam de dona Mariinha dão a esta última uma outra forma de se relacionar por meio da música, fato que gera disparidades entre as vivências de uma e de outra. É o mesmo território, mas as experiências de vida que as aproximam enquanto mulheres negras as diferenciam em medidas determinantes.

Jayne, de uma geração 68 anos mais jovem que dona Dalva e 48 anos que dona Mariinha, já se insere em um contexto completamente diferente ao vivenciado por suas precedentes. Também mulher negra vive em uma Cachoeira onde as mudanças comportamentais se sobressaem às mudanças políticas e sociais, estas que permanecem praticamente as mesmas ao longo das gerações. São três gerações que transitam pela cidade de distintas formas. 
Para situar essas questões, trabalharei com a linguagem e as escrevivências de cada interlocutora a partir das formas que elas se inserem na cidade e os trânsitos musicais que marcam suas trajetórias. Inspirada pela escrita de Conceição Evaristo (2016), mineira, mulher negra e uma das mais importantes escritoras da literatura negra brasileira, entendo escrevivência como a escrita que narra as vivências, que narra o que se vive. A análise dessas trajetórias será feita por intermédio da Análise Crítica do Discurso (ACD), recurso do campo dos estudos da linguagem que considera as reações entre linguagem e sociedade. De acordo com Maria Ceci Misoczky (2005, p. 130-131):

\begin{abstract}
A ACD trata a linguagem como discurso, e o discurso como elemento do processo social dialeticamente interconectado com outros elementos. Ou seja, o discurso é o uso da linguagem como uma forma de prática social, e a análise do discurso é a análise de como os textos funcionam inseridos em práticas socioculturais [...]. A ACD tem como propósito mostrar como o capitalismo se constrói através de processos de dominação, exploração e desumanização; e também como as contradições dentro do sistema constituem um potencial para o projeto de emancipação. A ACD vê os discursos como momentos na produção e reprodução material da vida social, e analisa o trabalho social feito por esses discursos como um foco importante da crítica social materialista [...]. Portanto, trata-se de uma prática conectada às lutas de resistência e por mudanças.
\end{abstract}

Dessa maneira, a investigação é feita através de reflexões sobre a trajetória das interlocutoras, por meio de suas composições. Para isso, é necessário colocar em evidência o contexto que marca a história de Cachoeira, político-social e culturalmente, bem como as histórias de resistência das mulheres negras nessa terra, em consonância com as transformações e o desenvolvimento brasileiro em torno da cultura popular. A escolha de trazer o samba de roda como aporte para a construção narrativa histórica e cultural de Cachoeira se dá pelo seu viés identitário, que surge num contexto diaspórico e por ser o principal elemento cultural que liga, em diferentes medidas, a história das três interlocutoras desta pesquisa.

\title{
1. Notas sobre Cachoeira: cidade heróica e de resistência de mulhe- res negras
}

Cachoeira é uma cidade energética. Algumas pessoas próximas já me diziam isso, algo que eu só consegui sentir já como moradora da cidade. Captar essa energia é um fato que exige percepção da sua importância histórica para a Bahia e para o Brasil, além de uma dose elevada de sensibilidade visual e auditiva. Andar pela cidade é reconhecer a influência que a exploração colonial exerceu sobre a região a cada faixada dos antigos casarões dos séculos XVIII e XIX.

Ao se aproximar de bairros um pouco mais afastados do centro é possível ouvir, em determinadas datas, o som dos atabaques que ressoa por entre as casas, levado pelo vento, o que anuncia a forte presença das tradições religiosas de matriz africana que resistem até os dias atuais. Não tem como se sentar na beira do rio Paraguaçu e não pensar ou imaginar os saveiros e navios que cruzaram essas águas ou quantas negras não se sacrificaram pela libertação de seus semelhantes nas lutas por independência. 
Não apenas Cachoeira, mas a própria região do Recôncavo cumpriu um importante papel econômico, territorial e histórico na época da exploração colonial. Região que se estende em torno da Baía de Todos os Santos, o Recôncavo possui aproximadamente $6.500 \mathrm{~km}^{2}$, 20 municípios e está localizado em uma área geograficamente estratégica no território baiano. No período da colonização assumia a função de ser o núcleo regional do processo de expansão dos interesses portugueses.

A construção da identidade cultural ${ }^{6}$ do Recôncavo e, por conseguinte de Cachoeira foi expressivamente influenciada pelo processo de colonização pelo qual passou, não só o Brasil, como também os demais países da América Latina. A dominação portuguesa do território brasileiro se deu por meio da visão expansionista e exploratória, que teve como marca a escravização de negras traficadas e a tortura e o genocídio de comunidades indígenas.

Com um território estrategicamente localizado, Cachoeira era considerada o portal de ligação entre o Sertão e Salvador, capital da província. A partir de 1532, data que registra a chegada das primeiras expedições na região, a localização e o solo fértil, propícios para o cultivo da cana-de-açúcar, atraiu exploradores e fez com que a economia dos engenhos ali se estabelecesse e se expandisse.

A partir de 1693, a instalação do porto permitiu a ligação fluvial da capital Salvador com o interior. A então Vila de Nossa Senhora do Rosário do Porto da Cachoeira, além de ver expandir o comércio local e a indústria fumageira, passa a ser via de importação e exportação, inclusive do tráfico de escravas negras contrabandeadas de países do continente africano (MARQUES, 2003).

[...] devido à expansão urbana das vilas próximas a Salvador e à zona fumageira, houve uma concentração expressiva de africanos nessa região do Recôncavo. Eram eles nagô, jeje, calabá, angola, cabinda, aussá, moçambique, binino, tapa, mina, são tomé e barba. Em 1824, salienta o pesquisador, com uma população que girava em torno de 6.000 habitantes, Cachoeira possuía um contingente de apenas 600 indivíduos brancos. A maior parte da população era de africanos (escravos e libertos) e crioulos. (NASCIMENTO apud MARQUES, 2003, p.8).

A formação social e seu consequente desenvolvimento urbano estiveram baseados na economia açucareira, fumageira e na agricultura de subsistência. Sua dimensão e riqueza territorial fizeram com que o Recôncavo aglomerasse um grande número de pessoas, principalmente a população negra, tanto escravizada quanto alforriada (NASCIMENTO, 2010; BARBOSA, 2010).

"A identidade cultural, por sua vez, é indispensável para a construção das representações sociais nos indivíduos". Resultante das interações sociais, esse transcurso surge como forma de justificar e explicar os fenômenos da vida humana a partir de uma perspectiva coletiva, que ativa a produção de consciência e, por conseguinte, de conhecimento. O sujeito, previamente vivido como tendo uma identidade unificada e estável, está se tornando fragmentado; composto não de uma única, mas de várias identidades, algumas vezes contraditórias ou não resolvidas. Correspondentemente, as identidades, que compunham as paisagens sociais "lá fora" e que asseguravam nossa conformidade subjetiva com as "necessidades" objetivas da cultura, estão entrando em colapso, como resultado de mudanças estruturais e institucionais. 0 próprio processo de identificação, através do qual nos projetamos em nossas identidades culturais, tornou-se mais provisório, variável e problemático. Esse processo produz o sujeito pós-moderno, conceptualizado como não tendo uma identidade fixa, essencial ou permanente. A identidade torna-se "celebração móvel". (HALL, 1999, p.12-13). 
O solo fértil fez multiplicar a quantidade de engenhos instalados na região e, a partir desse contexto, os perfis sociais e culturais baseados no modelo de sociedade colonizador e eurocêntrico foram sendo estruturados. "Além do engenho, coexistiam a casa grande e senzala, um núcleo patriarcal onde família e trabalho se mesclavam, formando o traço estrutural da vida cotidiana nos primeiros anos da colônia" (BARBOSA, 2010, p.15).

Assim como outras cidades, a outrora Vila de Nossa Senhora do Rosário do Porto da Cachoeira nasceu e começou a formar sua população colonial a partir do crescimento de rede urbana entre os engenhos. A expansão permitiu a formação das vilas e o desenvolvimento de atividades comerciais (BARBOSA, 2010).

A partir de 25 de junho de 1822, Cachoeira se projeta com um papel importante no cenário histórico e político nacional, quando se colocou como uma das primeiras cidades a organizar um movimento de enfrentamento ao governo português ao apoiar Dom Pedro I como príncipe regente do Brasil. As tropas que aqui se organizaram lideraram o movimento de resistência até culminar com a consequente emancipação do Brasil do domínio dos portugueses, em 7 de setembro do mesmo ano, a partir da declaração da Independência.

O movimento audacioso, que teve Maria Quitéria de Jesus ${ }^{7}$ como uma das comandantes da revolta, permitiu que em, 2 de julho de 1893, a Bahia conquistasse definitivamente sua independência de Portugal. Em 1937, após ser sede do governo provisório por duas ocasiões e por seu papel fundamental nos processos de Independência, Cachoeira foi elevada à categoria de cidade e recebeu o título de Heroica (MARQUES, 2003).

Entre os séculos XVIII e XIX a cidade viveu seu ápice. Zona de convergência entre o litoral e o Sertão, o porto localizado às margens do rio Paraguaçu era a principal rota de abastecimento para Salvador e de unidade regional. Sua localização privilegiada fez reunir um grande número de comerciantes do interior e da capital que traziam mercadorias para serem comercializadas na feira local. Com um solo propício para a produção fumageira, a navegação flúvio-marítima tornou a cidade principal ponto de escoamento do fumo que era produzido.

A mão de obra escravizada era a que tomava conta da produção agrícola e das lavouras. As mulheres negras, além de serem as responsáveis pelos serviços gerais nas casas grandes também eram exploradas nas lavouras pelos senhores de escravos. Elas que antes eram menos valorizadas na comercialização de mão de obra escrava, com declaração de ilegalidade do tráfico de negros e sua consequente proibição, como aponta a pesquisadora e importante intelectual negra brasileira Dora Bertúlio, especialista na área das relações raciais, passaram a ser prestigiadas pelos escravocratas por conta do seu potencial reprodutivo.

7 Maria Quitéria (1792-1853) é um importante nome nas lutas pela Independência da Bahia e do Brasil. Nascida na freguesia São José das Itapororocas, hoje Feira de Santana, se alistou no exército de voluntários para combater as tropas portuguesas. Escondida do pai, mas apoiada pela irmã, Maria Quitéria cortou os cabelos e, com vestes masculinas, se alistou sob o nome de Medeiros. Tempos depois foi descoberta pelos comandantes, mas, por sua habilidade no manuseio de armas e nas batalhas de campo, foi integrada com o seu nome de batismo e seu gênero. Vitoriosa em vários combates, Maria Quitéria foi homenageada com Ordem Imperial do Cruzeiro do Sul, condecoração que recebeu das mãos do próprio Dom Pedro I. Disponivel em: https://www.ebiografia.com/maria_quiteria/ Acesso em 3 jul. de 2017. 


\begin{abstract}
A reprodutividade/fertilidade das mulheres escravas tornou-se, no dia a dia das relações escravocratas, assunto de real importância no segundo quarto do século XIX, para a preservação do sistema e produção de lucro. Assim, o papel de ama de leite que as mulheres escravas domésticas exerciam no campo da maternidade, via de regra com a consequente perda de seu próprio filho, - órfãos, então e frequentemente encaminhados para os reservatórios (Casas de Correção) do Governo, torna-se duplo com o fim do tráfico, uma vez que, agora os ventres escravos estavam requeridos para produzir escravos e também criá-los à idade produtiva. (BERTULIO, 2001, p.7-8).
\end{abstract}

As mulheres negras já naquela época não só se inseriam na esfera privada, trabalhando na casa dos senhores de escravos, sendo amas de leite, cozinheiras, lavadeiras, como também participavam da vida pública trabalhando nas grandes lavouras e no comércio existente. Somadas sua condição de escravizada e sua raça/etnia, sentiam na pele a ferocidade da opressão interseccionada também pela classe e pelo gênero. A opressão sexual do corpo das mulheres negras era talvez a mais brutal, principalmente por serem tratadas como objeto e mercadoria pelos senhores de engenho. As que trabalhavam na casa grande eram obrigadas a servir aos desejos sexuais de seus senhores, sob risco de punição (GIACOMINI, 2013).

O racismo no Brasil e suas marcas culturais, econômicas e institucionais acarretaram uma desvalorização e depreciação não apenas do homem negro, mas, sobretudo, da mulher negra. A dominação racial e a supremacia branca na construção histórica do país datam desde o período da escravidão e se ampliam com o fim desse sistema com a instauração da Lei Áurea (1888). Porém, como enfatiza Dora Bertúlio ao traçar considerações sobre as discriminações de raça e gênero na sociedade brasileira e como elas se estruturam principalmente através do mercado de trabalho, as mulheres negras levam em sua história uma carga de exploração que marca sua força de trabalho e seus corpos, uma vez que servem como "uso e fonte de renda aos senhores e capatazes nas fazendas", e que "as escravas foram, ao longo dos 350 anos de escravidão, utilizadas como trabalhadoras do dia e da noite - o corpo utilizado em todas as suas possibilidades" (BERTÚLIO, 2001, p.24).

Com o fim do tráfico e a posterior assinatura da Lei Áurea, que aboliu o regime escravista, um grande número de negras libertas se juntou à população urbana economicamente ativa. Porém, "a população negra encontrou poucas alternativas fora dos trabalhos intermitentes e pequenas atividades subalternas" (NEPOMUCENO, 2012, p.385). Grande parte das mulheres negras foi trabalhar no comércio, vendendo quitutes e outras atividades de ganho, outras seguiram realizando trabalhos domésticos como cozinheiras e lavadeiras. Diante das relações de poder dentro de uma sociedade marcada pelo preconceito racial e pela seletividade de privilégios, os postos de trabalhado na indústria ocupados pela população negra eram para serviços inferiores e submissos.

De acordo com historiadoras e pesquisadoras (SANTOS, 2007; MARQUES, 2003; FILHO, 2012), o declínio de Cachoeira começou no final do século XIX, consequência de fatores políticos e econômicos que influenciaram diretamente em mudanças no mercado local e regional. Outro fator apontado para essa paulatina decadência foi o surgimento das rodovias que fizeram diminuir o tráfego marítimo-fluvial de embarca- 
ções pelo rio Paraguaçu e também o trânsito ferroviário, até então principais meios de transporte para o abastecimento e vazão de produtos do comércio local, bem como o escoamento da produção fumageira.

Já no século XX, o fechamento das fábricas de charuto e o deslocamento do grande comércio para a cidade de Feira de Santana, o desemprego e a pobreza aumentaram gradativamente na cidade (MARQUES, 2003). Atualmente, a cidade se mantém especialmente através do turismo cultural, principalmente por Cachoeira atrair um grande número de turistas brasileiros, sobretudo estrangeiros, que chegam diariamente na cidade em busca de sua riqueza histórica e das manifestações culturais e religiosas, já que o calendário festivo da cidade é repleto de atrações ao longo do ano.

O comércio se caracteriza pelo monopólio de algumas famílias oligárquicas e latifundiárias que possuem não apenas uma grande parte dos imóveis locais, mas também são donas de mercados, padarias e farmácias. Essas famílias se revezam ainda na liderança política, o que influencia de forma substancial para que o cenário de desigualdade econômica e étnico-racial não seja modificado. Em paralelo, a feira livre resiste ao longo dos anos à soberba política e à disputa com os grandes mercados. É nela que as pequenas produtoras moradoras da zona rural podem comercializar seus produtos, que são expostos quase que diariamente nas ruas que ficam em volta do Mercado Municipal, que se localiza logo na entrada da cidade. São comercializados frutas, verduras, carnes, pescados, grãos, animais, laticínios, ervas medicinais, produtos manufaturados, roupas, CDs, DVDs, calçados etc.

As desigualdades sociais, econômicas e raciais, estruturadas e intransponíveis no cenário cachoeirano, obrigaram, desde o início de seu declínio, o êxodo de nativos para outras cidades vizinhas, tendo como destino principal para a busca de melhores condições de vida e salários a cidade de Salvador. Ainda hoje a capital baiana é o destino escolhido, principalmente pela juventude, como alternativa à falta de oportunidade de empregos bem remunerados em Cachoeira.

\section{Herança da escravidão: O samba de roda no contexto da diáspora}

A música está diretamente entrelaçada ao contexto sociocultural da região. Por se manifestar por meio das pessoas, da vida cotidiana, das práticas individuais e coletivas através de memórias e histórias que perpassam e se mantêm por intermédio das gerações, o samba de roda, enquanto elemento de identificação cultural, se torna elemento primário de significação analítica, traço social de uma comunidade - por ser executada por pessoas - e parte essencial do estudo etnográfico, como defende a antropóloga inglesa Ruth Finnegan, a partir de uma "epistemologia musical" (FINNEGAN, 2002).

Os chamados "batuques", registrados desde o século XVIII em "danças ou bailes de africanos e descendentes que aconteciam em ruas, largos, casas e terreiros" (SANTOS, 1997 apud MARQUES, 2003, p.66), davam o ritmo através do tambor, das danças e celebrações ritualísticas de negras. A musicalidade estava presente no ambiente cotidiano 
de africanas e amefricanas ${ }^{8}$, principalmente nas situações de trabalho. Os cantos de trabalho eram uma forma de dinamizar e atenuar o cansaço de longas jornadas de produção braçal, mas também como estratégia de comunicação entre as trabalhadoras.

Estratégias de resistência e forma de comunicação de um povo que vive no cativeiro, os batuques e os cantos de trabalho não só amenizavam a dura realidade do trabalho escravo como atuaram também na construção de perspectivas identitárias, de pertencimento e enraizamento. Além de estimular e dar ritmo ao trabalho, os cantos reconceitualizam a cultura a partir do sentimento de desterritorialização. Esse processo de "reconceitualização" de uma cultura num outro sítio simbólico de pertencimento acontece por meio de hibridizações dentro de um novo território (SANTANA, 2012, p.35-36).

Os versos que surgiam durante a labuta eram reproduzidos e cantados em antifonia ${ }^{9}$ (chamado e resposta) nas rodas de música quando elas aconteciam. Quando se somava aos batuques, a viola e o pandeiro, "membranofone cuja membrana de couro é percutida com a mão e que tem platinelas afixadas à sua caixa acústica circular e muito rasa de madeira" (DINIZ, 2010,p.107), instrumentos portugueses incorporados e apropriados pelas negras, estava posto o samba de roda. De acordo com o Iphan (Instituto do Patrimônio Histórico e Artístico Nacional), os primeiros registros da ocorrência musical com esse nome e características datam dos anos 1860.

$\mathrm{Na}$ origem, o samba se formou em produção coletiva, em roda, formada por muIheres e homens. A salvaguarda do samba de roda como Patrimônio Imaterial da Humanidade ${ }^{10}$ foi um marco importante para o desenvolvimento social das cidades do Recôncavo, entre elas, Cachoeira. Antes do ano da patrimonialização ${ }^{11}$, os poucos grupos que existiam se reuniam em regime de resistência e perseverança, visto que o próprio poder público local não fomentava ou financiava a manutenção deles. Por serem, em sua maioria, de tradição familiar, alguns destes grupos não tinham sede ou realizavam reuniões de organização para as apresentações, que ocorriam na base do improviso, muitas vezes aconteciam sem o auxílio de aparelhos de sonorização, e toda a música que era executada acontecia na base da força do toque dos músicos.

$8 \quad$ Nomino as descendentes africanas e indígenas de "amefricanas", seguindo a linha de interpretação da filósofa e feminista negra Lélia Gonzalez, que em 1988, desenvolveu um estudo sobre a categoria político-cultural de amefricanidade, conceituada como "um processo histórico de intensa dinâmica cultural (resistência, acomodação,reinterpretação, criação de novas formas) referenciada em modelos africanos e que remetem à construção de uma identidade étnica" (GONZALEZ, 1988, p.76).

9 "A antifonia (chamado e resposta) é a principal característica formal dessas tradições musicais. Ela passou a ser vista como uma ponte para outros modos de expressão cultural, fornecendo, juntamente com a improvisação, montagem e dramaturgia, as chaves hermenêuticas para o sortimento completo de práticas artísticas" (GILROY, 2001, p.168)

10 O samba de roda foi proclamado Obra Prima do Patrimônio Oral e Imaterial pela Organização das Nações Unidas para Educação, Ciência e Cultura (Unesco) em 2005.

11 "O processo de patrimonialização foi guiado e conferido pela autarquia competente, o Instituto do Patrimônio Histórico, Artístico e Nacional - Iphan. Os títulos fazem parte das diversas promoções, realizadas pelo conjunto de políticas públicas que pretendem ampliar o campo discursivo acerca da cultura popular brasileira, proporcionando às diversas manifestações culturais, visibilidade, fazendo com que estas possam se manter ativas através de incentivos públicos" (CONCEIÇÃO, 2016, p.11) 
Com a salvaguarda, foram preservados também os saberes e fazeres de mestras e mestre do samba de roda. O reconhecimento e documentação de um repertório de cantigas de samba corrido, de samba chula e como passo de samba miudinho, aspectos que estão fortemente ligados aos terreiros de candomblé por suas semelhanças nos toques e gestos que fazem o samba de roda se assemelhar a um ritual, como confirma a etnomusicóloga Katarina Döring, "o samba de roda, como muitas tradições cênico-musicais de matriz africana, sempre foi música/dança/ritual com significados multifacetados enraizados na vida comunitária" (DÖRING, 2013, p.168).

Ainda segundo o estudo feito pela pesquisadora e etnomusicóloga Francisca Helena Marques (2003), em um profundo trabalho de investigação sobre o samba de roda do Recôncavo, os batuques eram característicos dos bailes de africanas e descendentes e foram altamente perseguidos pelo governo da Bahia na época, por aglomerar um grande número de escravas e de negras das mesmas nações. Foi com influência da Irmandade de Nossa Senhora da Boa Morte, surgida ainda no século XVIII e que reúne mulheres negras do Partido Alto, que o samba de roda se consolida como manifestação cultural popular negra e descendente.

Associado às principais manifestações religiosas, o samba de roda é considerado como música negra por sua influência que vem do lundu, dança popular e canção folclórica "de origem afro-negra, trazida pelos escravos bantos da região de Angola e do Congo" e faz alusão à cultura negra por sua "representação direta ou velada do universo afro-brasileiro", como defende o etnomusicólogo brasileiro Carlos Sandroni (SANDRONI, 2012, p. 42).Além de gênero musical, o samba de roda pode ser visto como instrumento de resistência política e cultural, onde a tradição segue sendo perpassada de geração em geração, muito relacionado à sua forte ligação ancestral.

As negras escravizadas eram submetidas a extenuantes jornadas de trabalho. A exaustão e a opressão eram amenizadas em tom de relutância, através de manifestações culturais próprias da identidade africana e de seus antepassados. A capoeira, o culto aos orixás, as comidas e os cânticos característicos do modo de vida transformado nostalgicamente e energeticamente em resistência e na luta por liberdade.

O mundo do Atlântico Negro, seguindo a mesma concepção de Paul Gilroy (2001), manteve latentemente viva a identidade cultural e a representação histórica dos povos através das manifestações culturais e expressões populares que mantinham uma ligação umbilical com seu território de origem dentro de um novo contexto geográfico, mantendo uma dupla consciência entre essas duas realidades existentes. Diante disso, os cantos de trabalho eram a tradição musical que traziam ao público características do cotidiano daquele grupo social. Não apenas as mulheres praticavam a tradição oral, como também os homens negros utilizavam a voz musicada como canal de comunicação e interação entre seus iguais.

Porém, as performances dos cantos durante o trabalho muitas vezes eram reprimidas pela perseguição da sociedade branca contra as manifestações culturais da população negra. A discriminação e o preconceito contra a diferença existente entre os dois povos deixaram desde sempre delimitadas as noções e/ou divisões culturais entre 
brancas e negras para aquilo que era classificado como sendo cultura "boa". Para essa definição, a influência estética que diferencia e hierarquiza as raças se reproduz sobre a noção de cultura legítima.

A miscigenação que nos forma enquanto nação, suplantada no imaginário coletivo a partir de hierarquizações baseadas num ideal de branquitude, acaba por refletir na definição da cultura, seja ela compreendida como cultura erudita ou enquanto cultura popular. Como uma das pontas das relações de poder existentes, a branquitude se constrói na ideia de uma superioridade estética, que privilegia brancos em detrimento de negros, indígenas, asiáticos e demais etnias, impondo à sociedade a crença da existência de uma "verdade" do belo, ideia que é determinante na sociedade e que se concentra no entendimento construído de uma superioridade moral e intelectual do branco europeu.

Assim, a cultura erudita - ou cultura mainstream - é concebida como sendo a alta cultura, a cultura branca, europeia, ligada ao entendimento positivista de uma cultura baseada na razão. Já a cultura popular - ou a cultura considerada ruim, vulgar - é entendida como sendo emotiva, irracional, comunitária, mais próxima da natureza, ligada à concepção romântica de povo, e surge em resposta contra "o racionalismo ilustrado", o que a torna "guardiã da tradição, isto é, do passado" (CHAUI, 1990).

Atrelada a experiências e práticas cotidianas de pessoas comuns, o samba de roda, enquanto elemento cultural se desenvolveu enraizado nas relações cotidianas e territoriais do Recôncavo, alcançou status de identidade nacional e se tornou, enquanto aspecto de consumo cultural, campo de disputa de uma hegemonia cultural, suscetível às contradições que surgem com a apropriação do popular pela cultura mainstream.

De acordo com o pensamento do intelectual negro Stuart Hall, sociólogo e um dos principais nomes dos estudos culturais, a cultura popular negra é constituída por tradições e práticas culturais populares e pela forma como estas se processam em tensão permanente com a cultura hegemônica (HALL, 1999).

Os fluxos migratórios ocasionados pelo êxodo de nativos para outras cidades do entorno de Cachoeira, principalmente para a capital, podem ser assimilados como importantes formas de influência nos trânsitos culturais que se formaram. As constantes idas e vindas, que começaram ainda no período pós-abolição e que forçaram negras a migrarem para outras regiões do país em busca de melhores condições de vida e emprego, marcam a formação da cultura afro-brasileira.

Um dos grandes exemplos que pode ser citado é a ida das Tias Baianas para o Rio de Janeiro no início do século XX, que influenciou o surgimento do samba moderno ao levar suas vivências marcadas através do samba de roda diretamente do Recôncavo para lá (GOMES, 2013; SANDRONI, 2012). Esses fluxos migratórios internos formaram, em outras territorialidades, comunidades a partir de "comunidades imaginadas" (HALL, 2008): ligações com seu lugar de origem que permitiram a (r)existência de povos negros em novos contextos de sobrevivência. 
Esse segundo fluxo diaspórico que marcou os trânsitos de amefricanas no Brasil incide diretamente na construção da identidade nacional e, por consequência, coloca em xeque mais uma vez o mito de um país de unidade a partir de uma democracia racial. O mito incide na generalização do país a partir de uma mesma identidade nacional, essa pensada com fixidez.

Porém, como explica Stuart Hall, "na situação da diáspora, as identidades se tornam múltiplas" (HALL, 2008, p.26), o que faz com que essa experiência, para as comunidades negras. as aproxime da ideia de pertencimento. Fato esse que possibilita até os dias atuais a luta do movimento negro na defesa das culturas de matrizes africanas. Ao pertencerem a um local de origem, as negras reafirmam sua ancestralidade e reivindicam a história de seus antepassados, evidenciando a brutalidade do processo colonizador na África e no Brasil.

\section{Marcadores sociais da diferença e linguagem musical: expressões das escrevivências cotidianas}

Os tensionamentos ocasionados entre o contato da cultura popular com a cultura hegemônica são perceptíveis no atual contexto cultural de Cachoeira. Os trânsitos culturais ocasionados pelos fluxos migratórios, a transformação populacional ocorrida com a chegada de novos moradores com a criação da universidade, além das influências midiáticas através dos meios de comunicação, bem como o acesso às novas tecnologias pelos nativos são fatores que trouxeram ares cosmopolitas à cidade.

As manifestações culturais tradicionais e características da cultura popular local agora dividem o lugar no calendário da cidade com eventos comuns da cultura urbana. Na música, no que pude perceber durante os trabalhos etnográficos em diferentes espaços sonoros, há uma diversificação na escuta de estilos musicais. Cachoeira é uma cidade extremamente musical. Rica em paisagens sonoras, a influência do samba de roda é perceptível a partir de suas ramificações, como o caso do pagode, gênero musical em que a maioria da juventude local está inserida. Porém, nas regiões mais à margem da cidade, além do pagode, o arrocha, o reggae e o rap são outros dos gêneros que estão presentes nos contextos cotidianos.

No dia a dia, é visível como a identidade cultural é marcada pelas diferentes formas de linguagem que se expressam na cidade. Podendo atuar como mediadora entre emissores e receptores (MARTÍN-BARBERO, 2009), a linguagem é entendida hoje dentro dos estudos da comunicação não apenas nos seus formatos tradicionais, como o rádio, a televisão e o cinema; ela causa efeito no processo comunicacional também através do vestuário, da música e do pertencimento, este entendido como linguagem no sentido político de pertencer a um determinado contexto histórico e social, em seu sentido subjetivo, mas também material (SOUSA, 1999).

Dessa maneira, é possível perceber formas de comunicação nas vestimentas das pessoas, na música que elas escutam ou até mesmo como lugares e espaços públicos medeiam mensagens entre seus frequentadores. Esses fatos são reconhecíveis, por 
exemplo, na associação das vestimentas das sambadeiras do samba de roda de dona Dalva. Vestidas de baiana, elas se apresentam em eventos e chamam a atenção pelo simbolismo que representam. dona Dalva definiu isso como forma de homenagear a avó, porém, hoje o grupo é reconhecido como um dos grupos mais charmosos do samba de roda justamente por essa identificação (MARQUES, 2003; IPHAN, 2006; QUEIRÓZ, 2016).

O protagonismo de dona Dalva na criação do grupo, bem como na definição de alguns elementos que hoje dão status que o diferencia dos demais grupos de samba de roda são resultados de sua identificação e pertencimento a uma determinada cultura. Ela trouxe elementos do seu cotidiano para compor o grupo. Além das vestimentas de baiana, as taubinhas ${ }^{12}$ de madeira que eram usadas na feitura dos charutos são agregadas ao samba e produzem uma sonoridade marcante, sendo, inclusive, instrumentos tocados pelas sambadeiras.

$\mathrm{Na}$ linguagem escrita é visível a utilização de itens do cotidiano e do contexto da dona Dalva como ingredientes para a composição do samba. Em uma de suas letras de maior destaque, feita em homenagem a Maria Tereza de Jesus - sua avó materna, que a criou até os seus 13 anos de idade -, a interlocutora narra com simplicidade um fato que marca sua vivência:

\author{
Maria Tereza \\ Ô Maria Tereza \\ Toma lá teu pedaço \\ Todo mundo tomou, tomou \\ Mas não teve embaraço \\ O embaraço que eu tive \\ Foi não ter meu dinheiro \\ Para comprar uma fita, \\ Uma fita \\ Para amarrar teus cabelo
}

Como é possível entender ao ler a letra, a música relata um momento onde dona Maria Tereza não tinha condições financeiras de comprar um laço de fita para amarrar os cabelos de dona Dalva na sua infância. As condições de trabalho as quais as mulheres negras eram submetidas forçavam horas exaustivas de trabalho, muitas vezes sem a remuneração merecida. Uma fita de cetim nos cabelos poderia ser preterida à necessidade real de sobrevivência. Assim, o discurso, baseado em uma experiência marcada

\footnotetext{
12 As tabuinhas de madeira, também conhecidas como "caqueiros" (FILHO, 2012) eram instrumentos utilizados pelas charuteiras durante a feitura do produto. As tabuinhas serviam para abrir as folhas que enrolavam o charuto. Os instrumentos foram aderidos por Dona Dalva e acompanham as sambadeiras durante a roda de samba e aparições. O som emitido pelas tabuinhas cumpre "a função de manter a linha-rítmica" (GRAEFF, 2015, p.76) do samba de roda.
} 
pela pobreza acompanhada pelo padrão ${ }^{13}$ rítmico-melódico e harmônico do samba de roda, revela a interligação do cotidiano como forma de expressão corporificada nas composições de dona Dalva.

A experiência, com a influência dos estudos de gênero no conhecimento acadêmico, tornou-se uma categoria que passou a ser relevada na análise do caráter da opressão sobre as mulheres, além de colocar a subjetividade dos indivíduos como fonte de conhecimento e historicidade (GOMES; ROSA, 2015). Assim, é possível entrelaçar as experiências de vida de dona Dalva na construção de seu texto, do discurso textual que posteriormente se constitui uma sonoridade. $O$ discurso pode ser entendido como uma construção linguística que está intrínseca ao contexto social sendo diretamente determinado pelo contexto político e social de suas autoras e autores (ROCHA; DEUSDARÁ, 2005).

Outra música, também composição de dona Dalva e que é a segunda faixa do disco "Samba Baiana: A vivência cantada de Dona Dalva", lançado em 20114, Minha Oyá, apresenta elementos do trânsito musical existente na trajetória da interlocutora. Candomblecista filha do orixá Obaluaê, é integrante da Irmandade de Nossa Senhora da Boa Morte ${ }^{15}$, grupo que reúne mulheres negras idosas e organização influente por sua importância na representação da negritude e afirmação cultural e política. Isso pode ser reafirmado durante Marcha das Mulheres Negras Contra o Racismo, a Violência e Pelo Bem Viver, realizada em Brasília no dia 20 de novembro de 2015. Cerca de 50 mil mulheres negras organizadas em diversos coletivos e movimentos de mulheres negras do Brasil se juntaram na capital federal para reivindicar cidadania plena, o combate ao racismo, sexismo e todas as formas de violência. Na frente da Marcha estavam as Irmãs da Boa Morte, e foi das mãos delas e de representantes dos movimentos organizadores que a então presidenta do Brasil, Dilma Rousseff, recebeu a carta com as reivindicações do movimento ${ }^{16}$.

Assim, desde o lugar de devoção de dona Dalva às suas guias, pode-se perceber que a letra mostra sua adoração à Santa Bárbara, lansã (Oyá), na negociação sincrética entre o candomblé e o catolicismo popular, e conota a relação intrínseca que a compositora tem com ambas as religiões.

\footnotetext{
13 Segundo Nina Graeff (2015), utilizando referências de Merriam (1956), o samba de roda tem padrões melódicos semelhantes aos que caracterizam as melodias africanas no candomblé ketu: "tendência a frases melódicas descendentes; extensão curta (cerca de uma oitava); sequências de segunda maiores, terças e quartas; ausência de modulação; ornamentação típica africana: portamento - ou glissando - ataque ascendente (rising attack) e finalização descendente (falling release); canto responsorial/call-and-response" (MERRIAM, 1956 apud GRAEFF, 2015 , p.43). Para mais informações sobre o padrão musical do samba de roda, ver também Döring (2016).

14 CD disponivel para audição em: https://www.youtube.com/watch?v=xZriHdQ_CMg.

15 "A Irmandade de Nossa Senhora da Boa Morte é um coletivo de mulheres idosas, todas religiosas enquanto praticantes do candomblé e do catolicismo popular. Como grupo, a Irmandade é considerada pioneira na luta e resistência do negro contra o sofrimento e a escravidão no Brasil. As irmãs foram e são mulheres diferenciadas em vários sentidos: aos olhos da sociedade colonial, eram chamadas de 'negras do partido alto'; miticamente transgressoras da ordem masculina são consideradas 'iamis' e organizadas em sacerdócio religioso, unindo diferentes nações são donas do axé ou 'eleyes'. As irmãs antigas compraram as alforrias de outros sacerdotes e sacerdotisas africanos, se comprometeram em garantir funerais dignos a si mesmas e aos seus, e mantêm uma festa associada aos seus antepassados femininos (eguns) e aos seus orixás durante rituais católicos públicos e do candomblé (secretos). Segundo as irmãs, elas cumprem uma promessa feita pelas mais antigas: 'se todos os escravos fossem libertos, elas cultuariam Maria na vida e na morte" (MARQUES, 2008, p.5).
}

16 SILVA, Cidinha. Para onde caminha a Marcha das Mulheres Negras. Diário do Centro do Mundo, 20 nov. 2015. Disponivel em http:// www.diariodocentrodomundo.com.br/para-onde-caminha-a-marcha-das-mulheres-negras-por-cidinha-da-silva/. Acesso em 3 maio 2017. 


\author{
Minha Oyá \\ Minha Santa Barbra \\ Aê, minha Oyá \\ Ôh minha Santa Barbra \\ Aê minha Oyá \\ Anágua rendada \\ Ponta de punhal \\ Eu vi trovejar \\ Aê minha oyá \\ Oh, Minha Santa Barbra \\ Levanta povo venha ver \\ O samba de roda e dendê \\ Levanta povo venha cá \\ O Samba de Roda de Oyá \\ Oh Minha Santa Barbra \\ Que bela coroa \\ Pelo amor de Deus, Santa Barbra \\ Não me deixe atoa
}

A associação da figura de Santa Bárbara, protetora contra relâmpagos e tempestades, imagem católica que representa uma mulher branca, à lansã, orixá negra rainha dos ventos e raios, é consequência dos anos de negociação ao quais os povos negros foram obrigados a manter para que as culturas de matriz africana pudessem coexistir. A perseguição à religião e a outros elementos da cultura ancestral foram episódios recorrentes no final do século XIX e persistem até os dias atuais, mesmo que os direitos de livre manifestação e culto a essas formas de manifestação da cultura negro-africana estejam garantidos na Constituição brasileira de 1988.

$\mathrm{Na}$ letra acima essa transversalidade é nítida. A compositora usa elementos característicos de ambas as entidades para descrevê-las e que têm como base sonora o pandeiro e o timbal, instrumentos sonoros que dão o ritmo tanto nos sambas de roda quanto nas rodas de samba nos terreiros de candomblé. Anágua rendada, punhal, trovão, elementos associados à lansã (Oyá), e a coroa (a imagem da santa acompanha ainda o cálice e a espada) como elemento símbolo da santa católica. Essa composição indica ainda o trânsito que a interlocutora faz entre as duas religiões, sendo praticante do candomblé e participante devota do catolicismo popular, bem como é característico também do próprio trânsito que faz samba de roda, que é executado tanto nas festas e rezas para santidades católicas, como é tocado nas festas nos terreiros em homenagem aos orixás.

$\mathrm{Na}$ transcrição dessa letra, fiz questão de manter a pronúncia de dona Dalva. Tinhosa, a compositora traz em sua maneira de cantar as suas próprias características e a forma que usa a linguagem no seu cotidiano. São contrações e um jeito diferente de lidar com o português, língua dominante em nossa trajetória cultural e herança da colo- 
nização portuguesa. A forma de falar de dona Dalva representa uma linguagem que até os dias de hoje é falada principalmente pelas mais velhas e tida pela norma culta e pela branquitude como uma linguagem de pronúncia errada.

Entretanto, a filósofa e importante pensadora negra brasileira, Lélia Gonzalez, afirma a existência do pretuguês (ou pretoguês) como herança linguística dos povos escravizados. Ainda de acordo com Lélia, no Brasil se tem uma linguagem africanizada que é negada e não aceita pelo padrão da gramática normativa. Ela diz:

[...] aquilo que chamo de "pretoguês" e que nada mais é do que marca de africanização do português falado no Brasil (nunca esquecendo que o colonizador chamava os escravos africanos de "pretos" e de "crioulos", os nascidos no Brasil), é facilmente constatável sobretudo no espanhol da região caribenha. O caráter tonal e rítmico das línguas africanas trazidas para o Novo Mundo, além da ausência de certas consoantes (como o l ou o r, por exemplo), apontam para um aspecto pouco explorado da influência negra na formação histórico-cultural do continente como um todo (e isto sem falar nos dialetos "crioulos" do Caribe). Similaridades ainda mais evidentes são constatáveis se o nosso olhar se volta para as músicas, as danças, os sistemas de crenças etc. (GONZALEZ, 1988, p.70).

Em seu trabalho que reflete sobre a construção do racismo e do sexismo na cultura brasileira, Lélia Gonzalez o escreve todo usando o pretuguês, o que deixa evidente o seu posicionamento político ao afirmar a linguagem como possibilidade de construção de conhecimento. Na obra ela ainda questiona sobre as noções de consciência, que, para ela, "se expressa como discurso dominante" e que pode ocultar a memória, "lugar de inscrições de uma história que não foi escrita" (GONZALEZ, 1984, p. 226). A memória, nesse caso, é dos povos escravizados, que, ao longo da história da constituição brasileira, tem suas origens apagadas dos registros oficiais. Assim, ela arremata:

É engraçado como eles [sociedade branca elitista] gozam a gente quando a gente diz que é Framengo. Chamam a gente de ignorante dizendo que a gente fala errado. E de repente ignoram que a presença desse $r$ no lugar do I nada mais é do que a marca lingüística de um idioma africano, no qual o l inexiste. Afinal quem é o ignorante? Ao mesmo tempo acham o maior barato a fala dita brasileira que corta os erres dos infinitivos verbais, que condensa você em cê, o está em tá e por aí afora. Não sacam que tão falando pretuguês. E, por falar em pretuguês, é importante ressaltar que o objeto parcial por excelência da cultura brasileira é a bunda (esse termo provém do quimbundo, que, por sua vez e juntamente com o abundo, provém de um tronco lingüístico bantu que "casualmente" se chama bunda). E dizem que significante não marca... Marca bobeira quem pensa assim. De repente bunda é língua, é linguagem, é sentido, é coisa. De repente é desbundante perceber que o discurso da consciência, o discurso do poder dominante, quer fazer a gente acreditar que a gente é tudo brasileiro, e de ascendência européia, muito civilizado, etc e tal [...]. E culminando pinta este orgulho besta de dizer que a gente é uma democracia racial. Só que quando a negrada diz que não é, caem de pau em cima da gente, xingando a gente de racista. Contraditório, né? Na verdade, para além de outras razões, reagem dessa forma porque a gente põe o dedo na ferida deles, a gente diz que o rei tá pelado. E o corpo do rei é preto e o rei é escravo (GONZALEZ, 1984, p. 238-239, grifos da autora). 
Enquanto fenômeno, a linguagem é considerada como construção social e é meio de dominação justamente por ser "um sistema de diferenças" (SILVA, 2000). Para explicar a relação de exploração entre povos dominantes e dominados e como ela causa severos danos psicológicos aos povos da diáspora africana, Frantz Fanon, em Pele Negra, Máscaras Brancas, coloca a linguagem diante desse contexto. Para ele, "falar é estar em condições de empregar certa sintaxe, possuir a morfologia de tal ou qual língua, mas é sobretudo assumir uma cultura, suportar o peso de uma civilização" (FANON, 2008, p.33).

Ao impor uma linguagem, o colonizador abre precedentes que inferiorizam os povos negros, subjugam sua capacidade linguística e cultural. Porém, como o próprio Fanon aponta, "um homem que possui a linguagem possui, em contrapartida, o mundo que essa linguagem expressa e que lhe é implícito" (FANON, 2008, p. 34). Assim, ao mesmo tempo em que a linguagem é utilizada como forma de inferiorização, se torna caminho de resistência ao ser apropriada e ressignificada. O samba de roda, que nasce dentro da senzala (MARQUES, 2008), se torna linguagem e prática de resistência dentro da uma sociedade que surge da lógica colonialista moderna e que coisifica a subjetividade e os corpos negros.

O zelo e a difusão da linguagem do pretuguês é um ato de resistência, principalmente por se tratar de uma linguagem comum em sua forma oral. Enquanto elemento do cotidiano, ela é traço da fala e da escrita de mulheres negras. Seu registro se dá, sobretudo, por meio da literatura negra, sendo muito presente nas obras de escritoras negras brasileiras, como Carolina Maria de Jesus, Conceição Evaristo e Cidinha da Silva. Todas contam histórias a partir de escrevivências particulares ou narram as de mulheres próximas, pessoas comuns, mas que se aproximam de suas realidades. Nas narrativas é comum as escritoras utilizarem o pretuguês como linguagem híbrida à normativa.

Enquanto influenciadora cultural, o legado de dona Dalva é representativo. Suas composições, que são atos de escrevivências, versam também sobre situações coletivas ou opressões em comum que viveram mulheres do samba de sua geração e de gerações após a dela. Outra composição que deve ser destacada nessa pesquisa é da música Marido vou pra o Samba. Na letra, a compositora narra a negativa do homem em acompanhar a mulher no samba, que seria uma zuada.

Marido, eu vou pra o samba.

Mulher eu lá não vou

Se eu gostasse de zuada

trabalhava num trator

Mulher eu lá não vou

Não vá que eu lá não vou

Não vá que lá não vou

Mulher eu lá não vou 
A resposta do marido pode ser entendida, a partir da perspectiva dos estudos feministas, como um reflexo machista de desmerecimento à produção musical feita por mulheres. Se, como a própria revelou em uma de suas falas no filme Dalva, o samba de roda era desmerecido por ser coisa de preta, como podemos imaginar essa situação frente a uma liderança feminina num mundo patriarcal? A resposta é dada pela própria dona Dalva, que defende (MARQUES, 2003) que só é samba de roda se houver sambadeiras; caso contrário, é um sambão. Mais uma vez, ela politiza sua trajetória e fortalece o protagonismo de outras mulheres negras no samba de roda.

A música, como forma de expressão e representação pode atravessar a experiência de diversas pessoas. Ao ouvir essa música e refletir sobre seu significado, me lembrei de uma conversa que tive com dona Mariinha durante a fase de pré-campo, em junho de 2015. Durante o diálogo pude perguntá-la sobre sua relação com a música e, especificamente, como era para ela assumir seu papel de sambadeira publicamente no seu passado, quando o samba de roda ainda era uma manifestação pouco valorizada.

Viúva há alguns anos, dona Mariinha disse que tinha uma boa relação com o esposo, mesmo quando o assunto envolvia sua participação ou presença em festas onde aconteciam o samba de roda. Segundo relato, ele não gostava que ela fosse ao samba. Se pensarmos que a participação de mulheres em espaços públicos, a exemplo das rodas de samba e seu contexto de vadiação, nunca foi bem vista aos olhos de uma sociedade patriarcal, o contexto no qual essa interlocutora se insere evidencia a contradição de universalizar a experiência das mulheres.

Isso se torna específico se tentarmos encaixar a experiência de dona Mariinha em um dos postulados da teoria feminista clássica, a da dicotomia público/privado (NICHOLSON, 1992) e da demarcação casa/rua, que institui "lugar de mulher" e "lugar de homem", presentes na lógica patriarcal de sociedade responsável pela redução do papel da mulher à esfera doméstica.

Contudo, visto que o caso da experiência das mulheres negras se distingue dessa lógica especialmente porque o feminismo hegemônico é pensado a partir do sujeito mulher ocidentalizado e da experiência das mulheres da classe média, o marco público/privado nunca atravessou a experiência das mulheres negras da mesma forma que acontece com mulheres de classe média branca. É o que salienta a intelectual negra brasileira Luiza Bairros, ao afirmar que certas categorias e princípios cruciais da teoria feminista abrem precedentes para generalizações (BAIRROS, 1995).

Dessa maneira, a opressão sexista que dona Mariinha passava ao contrariar a vontade do marido ao ir ao samba não chegava a ser um impeditivo para que ela exercesse seu livre-arbítrio de estar presente em rodas de samba quando quisesse. É através da experiência dela que podemos perceber como determinadas opressões não se aplicam da mesma forma a uma categoria heterogênea como é a das mulheres. 
Ele não gostava, mas ele não me impedia... e eu ia assim mesmo. Sempre eu ia. Antes a vida era assim. A mulher ficava só em casa para cuidar dos filhos. $\mathrm{O}$ marido que trabalhava né? Mas hoje em dia as mulheres querem ser independente. Não quer ficar em casa pra tomar conta de filho, nem cozinhando, nem lavando, nada disso. Quer trabalhar pra ter a vida dela livre também, porque quando um homem bota uma cadeira dentro de casa, ela bota uma mesa. Quando ela bota uma geladeira, ele bota uma televisão. E aí, comé que diz? Vão prosperar. Eu acho que seja isso mesmo (Depoimento registrado pela pesquisadora em junho de 2015)

O esposo não gostava muito de acompanhá-la nos sambas, mas isso não impedia sua autonomia de frequentar festas onde tinha samba de roda. Entretanto, por mais que o samba de roda venha de uma tradição que o "aproxima de sua carga feminilizadora do mundo negro, do ritual afro-religioso, território de poder feminino" (GOMES, 2013, p. 358), não está distante das tramas sexistas que formam a sociedade. Assim, como já salientado aqui, a ideia de mulheres negras produzindo samba de roda ou participando de rodas de samba, que vem de um contexto de vadiação, não era bem-vista por grande parte da sociedade.

Assim, o fato de a caracterização e composição do Samba de Roda Suerdieck ser por intermédio da liderança de mulheres negras - mesmo que os papéis sociais sejam marcados - me parece atos cotidianos de resistência e protagonismo político e musical, principalmente pela Casa do Samba ser agente de formação que preza a preservação do patrimônio cultural.

Enquanto elementos de significação e que compõem o Samba de Roda Suerdieck como uma manifestação cultural da tradição musical do recôncavo, as vestimentas, a sonoridade executada e as composições dos sambas de roda são diferentes formas de comunicação associadas à cultura popular. Por sua capacidade de identificação e representatividade subjetiva, mas também como potência de ação comunicacional que produz materialidade discursiva em contato direto com o cotidiano de suas produtoras, são associadas aqui nessa pesquisa como possibilidades de serem entendidas como práticas de comunicação popular.

Esse entendimento se estrutura por afirmações de que as linguagens, junto com a dança e a música, são consideradas pelos postulados da etnomusicologia como formas de comunicação (SEEGER, 2008). Assim, por se caracterizar diferentemente da grande mídia e, principalmente, por se manifestar por meio de ações de grupos populares (PERUZZO, 2008), o samba de roda pode ser entendido como prática de comunicação popular.

\section{3. "Vamo meter as caras": o rap reconfigurando os espaços de pro- tagonismo de jovens negras através da música em Cachoeira}

Nas andanças pela cidade e nos espaços onde o samba de roda geralmente se realiza, sempre percebi uma participação significativa de mulheres - crianças, jovens, adultas, idosas -, particularmente quando as apresentações do samba acontecem em praça pública. Uma das observações de campo que trouxe reflexões significativas foi a 
de que no atual momento, quando os grupos de samba de roda falam de preservação e de valorização, vê-se surgir novos grupos com o objetivo de resgatar e manter a tradição do samba. Contudo, esse movimento segue sendo predominantemente masculino.

As observações de campo me levaram a refletir ainda como as tecnologias se tornam cada vez mais palpáveis no contexto cotidiano de uma juventude que anseia por novidades. É comum andar na rua da cidade e ver vários jovens reunidos nas praças, lanchonetes ou próximos de lugares onde tem sinal de wi-fi aberto, sendo às vezes suas únicas formas de ter acesso à internet livre. Com o mundo nas mãos através dos celulares, elas podem se deslocar para outros lugares, talvez uma fuga de uma realidade social e econômica que não permite perspectivas diferentes das que elas possuem.

O deslocamento cultural propiciado pela chegada da Universidade ${ }^{17}$ sobrepôs em contato distintas sociabilidades, mas também destaca o próprio processo de deslocamento de uma cultura que está em constante transformação. Mudanças essas que são, sobretudo, ocasionadas pelos processos comunicativos que se ampliaram com a internet, um sistema eficaz de troca de informações. Os deslocamentos de diferentes sujeitos dentro de uma mesma cultura nos leva, ao movimento que a socióloga Goli Guerreiro nomeia como diáspora virtual, que caracteriza a chamada Terceira Diáspora:

Terceira diáspora é o deslocamento de signos - textos, sons, imagens - provocado pelo circuito de comunicação da diáspora negra. Potencializado pela globalização eletrônica e pela web, coloca em conexão digital os repertórios culturais de cidades atlânticas - ícones, modos, músicas, filmes, cabelos, gestos, livros (GUERREIRO, 2010, p.10, grifo da autora).

Os trânsitos culturais que ocorrem com as diferenças geracionais entre as interlocutoras dessa pesquisa nos levam a entender como surge a influência do rap enquanto espaço possível de atuação e de protagonismo para jovens negras em Cachoeira, a exemplo de MC Jayne. O contato com o rap, além do acesso convencional através dos meios de comunicação de massa, foi colocado a ela e a tantas outras jovens por meio das aulas de dança de hip hop que aconteciam em projetos como na ONG GAMGE e de iniciativas pessoais, como o grupo de street dance, ABW Crew. Jayne que teve sua iniciação artística frequentando as apresentações do Samba de Roda Flor do Dia, hoje transita no universo musical através do rap.

Tendo em mente a categoria de mulheres negras como uma identidade heterogênea, não fixa, é possível pensar que as transmutações dos espaços musicais onde essas mulheres negras se inserem podem se configurar também como processos de atualização das dinâmicas sociais e econômicas, bem como da própria ideia de identidade cultural. Essa, também captada enquanto categoria não fixa, me leva a entender os contextos atuais como fatores indissociáveis na construção de novos espaços do protagonismo dessas jovens negras dentro do campo musical popular na cidade.

\footnotetext{
17 Creio que essa dinamicidade e afetação cultural foi uma das mais interessantes influências que a chegada da Universidade Federal do Recôncavo da Bahia (UFRB) trouxe em 2006 para o Recôncavo. Em Cachoeira foi instalado o Centro de Artes, Humanidades e Letras (CAHL), que tem sua vida acadêmica concentrada no Quarteirão Leite Alves, mesmo local onde por muito tempo funcionou a sede da charutaria Leite Alves. Os cursos das áreas de concentração atraíram para Cachoeira uma diversidade de pessoas, uma juventude urbana que, de fato, trouxe impactos para a cidade, positiva e negativamente.
} 
A primeira composição de Jayne foi Mina Favelada. A primeira vez que escutei a música foi por meio de um vídeo publicado no YouTube de uma apresentação dela no Cinetheatro Cachoeirano, em um evento beneficente. A letra chama atenção pela simplicidade das rimas.

\section{Mina Favelada ${ }^{18}$}

Eu tô chegando e vou mandando aqui no movimento

Escutando essa batida pode crê que eu não aguento

Rap e o hip hop tá na veia meu irmão

Tô falando é de verdade mano, né de boca não

Dentro de casa escrevendo o meu rap pra valer

Se deixar eu vou rimando até o dia amanhecer

Porque o rap nunca sai da minha cabeça

Eu ando me controlando antes que eu enlouqueça

Tenho amor pelo o que eu faço e ninguém mim tira dessa

Para o povo que critica isso aí não me interessa

Eu quero é crescer a cada dia mais

Fazendo altas rimas porque eu gosto demais

No movimento tem mais mano e tem poucas minas

Represento sem miséra e sempre com autoestima

Mas as minas vão chegar e representar daquele jeito

Tudo junto e misturado na favela e no gueto.

\section{Refrão}

Tá ligado que essa é a nova versão

Jayne vem chegando e mandando a improvisação

Se liga só que essa é a parada

Eu chego no rap e mostro que

Eu sou uma mina favelada. $(2 x)$

Ando na ativa o tempo todo

Porque eu sou pivetona no meu gueto

Tá ligado, tranquilona

Tranquilidade pra chegar

Epra constar

Eu chego no bagulho

E aqui é nóiz que tá

Sou negra e tenho atitude

De cantar em qualquer lugar

Porque o rap me faz bem

E eu não tenho o que falar 
Vou seguindo na missão

Eu tenho muito a caminhar

A MC aqui não falha

E chegou pra representar

A mente vai trabalhando

$E$ você vai se expressando

Encaixando as palavras

Eu sigo na vida rimando

Eu vivo sim! daquele jeito

Combatendo o machismo

E também o preconceito

Pega a visão

Escuta aí que o papo

Já foi dado pela mina $M C$,

Eu quero é muito mais respeito

E também evolução

Nesse mundo que vivemos

Tem muita destruição

Repete refrão

Respeito é uma palavra

Que existe em todo lugar

Só que muitos não respeitam

Tem que aprender respeitar

O mundo está perdido

Aumentando a violência

As crianças sem saber

Tão chegando na inocência

Nesse mundo tem de tudo

Por isso tem um porém

Existe o lado mau

Também o lado bem

Mães irresponsáveis

Que abandonam as criancinhas

Eu vejo os pais comendo as filhinhas

Antigamente essas coisas eram na televisão

Agora é perto de você

Isso não é mentira não

Por isso cada um escolhe o que quer da vida

Alguns tão trabalhando

E outros na vida bandida 
O movimento aqui é grande

Fique atento meu irmão

Sou eu sou a Jayne

Expressando essa canção

Então fica ligado nessa batida

Porque eu já mandei meu papo

E essa é minha disciplina

woll...

A letra revela uma combinação de sílabas tônicas e palavras que têm sonoridades próximas, marcadas por um beat que tem como base o boom bap. Considerado dentro do rap como um estilo old school, o boom bap é umas das batidas clássicas do gênero musical que tem o bumbo e a caixa como principais instrumentos de marcação. Analisando o discurso da letra, é possível perceber que a compositora coloca na primeira e segunda parte da música alguns aspectos da sua relação com o rap e como acontece seu processo criativo. Ela usa gírias que são comuns dentro do movimento hip hop como "tá ligado", "mano", "mina”, "pega a visão", "favela" e "gueto", expressões características do contexto dos grandes centros urbanos.

Ela segue e diz que seu rap é para combater formas de opressão machista e preconceitos. Ela também se auto afirma negra e que isso lhe confere atitude de cantar o rap. Na estrofe final ela conta sobre como o respeito é um valor que tem se perdido e narra casos de abandono, estupros e violência. A última parte da música chama a atenção sobre como ela coloca os casos de abandono e de estupros de crianças pelos pais como casos que aconteciam longe, que só eram possíveis de serem vistos pela televisão, e que agora acontecem perto dela.

É interessante observar que ela se apropria de uma linguagem urbana, mas fala a partir de seu local, da sua realidade, configurando de certa maneira uma linguagem que destoa do discurso masculinizado predominante no gênero musical. $O$ rap, que surge num contexto de luta por direitos civis na cidade de Nova York, no final da década de 1970, se formata como linguagem de contestação de negras e imigrantes latinas que habitavam um dos bairros mais pobres da cidade, o Harlem, composto em sua grande maioria por homens.

Considerado como periférico, o bairro na época possuía altos índices de assassinatos, assaltos, tráfico de drogas e um contexto de miserabilidade. A música surgiu como alternativa para jovens negros e latinos que se enfrentavam em brigas de gangues. O rap (a música), junto com o grafite (arte visual em muros), o break (a dança) e o DJ (que garante o beat) são os quatro elementos que dão ao hip hop a característica de um movimento de juventude (FREIRE, 2011).

Associada como uma "forma de narrativa contemporânea" (RODRIGUES, 2013, p.34) a música rap se expandiu para diferentes lugares, especialmente nas periferias de cidades de contextos urbanos, por meio de mídias como a televisão e o rádio, alcan- 
çando também cidades do interior através da internet, principalmente nos dias de hoje. No Brasil o movimento hip hop e o rap começam a ganhar força na década de 1980 nas principais capitais do país (FREIRE, 2011; RODRIGUES, 2013).

As composições, os depoimentos concedidos por Jayne à pesquisa e o convívio com ela me fazem compreender seu processo de inserção no rap e a apropriação da linguagem como forma de expressão, bem como seu deslocamento dentro da cultura popular negra. De gênero representativo de um contexto histórico ancestral para uma música moderna. O rap é a linguagem que reflete a posição social que ela ocupa em um contexto de insurgências culturais.

No rap, a linguagem é direta, para "bater certo". O tom usado é o de denúncia social, de posicionamento frente às desigualdades e de busca de enfrentamento destas por meio da música. Segundo o cientista social e pesquisador Roberto Camargo de Oliveira (2015), o rap é além de gênero musical, campo da cultura política, é aliança entre arte e resistência dentro de um padrão contra-hegemônico de linguagem musical.

Assim como o samba é pensado dentro de uma lógica polissêmica, o contexto social do qual emerge o rap deve ser entendido a partir do seu potencial polifônico. Parte de um conjunto de elementos que formata o movimento hip hop com sua capacidade de contestação, o rap é linguagem representativa de sujeitos dissonantes (OLIVEIRA, 2015).

Numa realidade onde a juventude atua para quebrar os padrões que são impostos por uma sociedade normativa e opressora, a música, principal produto cultural consumido por jovens (RODRIGUES, 2013), através de sua potência de ação comunicacional, desloca Jayne para um papel que aos poucos ela percebe que é representativo não só para ela.

Assim como o legado da escravidão cravou na identidade das mulheres negras a exploração não apenas de sua força de trabalho, mas também a exploração sexual e a hipersexualização de nossos corpos, marcou ainda o nosso lugar de subalternidade na sociedade, que passa também pela produção criativa das mulheres nas artes. É por meio da compreensão da categoria de mulheres negras de forma não essencializada, mas passível de contaminação ao se interseccionalizar com outros marcadores sociais, que a música pode se caracterizar como prática discursiva opressiva e opressora, sobretudo quando associada ao mercado hegemônico, onde músicas de cunho depreciativo às mulheres são comuns.

A partir do termo interseccionalidade, alcunhado pela filósofa negra estadunidense Kimberlé Crenshaw (2000), usado para identificar as diferenças dentro da diferença, ao ser posto como conceito analítico da experiência das mulheres negras, é possível perceber como o gênero e o marcador da diferença étnico-racial se articulam para gerar diferentes formas de opressão, formas essas entrecruzadas e que possibilitam às mulheres negras a terem um olhar diferenciado sobre a sociedade em que vivem. 
É a partir dessa perspectiva que a música pode ser entendida por seu potencial comunicativo contra-hegemônico, que abre a possibilidade de transformação ao deslocar e permitir a transitoriedade nos contextos em que esses indivíduos estão inseridos e que por ela tem suas trajetórias interligadas, fazendo de suas experiências pessoais e coletivas discursos musicais empoderadores.

As histórias de parecenças (EVARISTO, 2016) em suas experiências de vida e nas de mulheres e demais pessoas em volta, marcam as escrevivências de dona Dalva, dona Mariinha e MC Jayne e desafiam a lógica da estrutura dominante. As escritas de mulheres negras, baseadas em seus cotidianos e de suas comunidades, são fontes de representatividade, diálogo, compartilhamento e, sobretudo, formas de comunicação popular, ao usarem a música como meios próprios dessa inter-relação.

As escritas dialogam não apenas com suas autoras, mas com as pessoas que estão recebendo a mensagem e que têm o poder de decodificá-las, interpretá-las ou não. Esteticamente, os gêneros musicais se diferenciam, mas a sua potencialidade é de resistência. Como linguagens musicais que podem ser capazes de exercer ação comunicacional, o samba de roda e o rap são gêneros musicais eficazes enquanto meio de reverberação de enfrentamento, representação e crítica, seja a partir da mensagem, seja pela estética que é produzida e exposta.

As semelhanças e diferenças entre as vivências e os contextos onde estão inseridas as interlocutoras aproximam suas realidades, o que potencializa o entendimento da música como produtora de materialidade por meio da linguagem. Assim, dotada da capacidade de influenciar nos processos de protagonismos de mulheres negras, a música, dentro do contexto do campo pesquisado, pode vir a ser caracterizada como comunicação popular per se.

\section{REFERÊNCIAS}

BERTULIO, Dora Lúcia de Lima. Racismo, violência e direitos humanos: considerações sobre a discriminação de raça e gênero na sociedade brasileira. 2001. Disponível em: https://www.academia.edu/16050466/RACISMO_VIOL\%C3\%8ANCIA_E_DIREITOS_ HUMANOS. Acesso em 9 out. 2015.

BAIRROS, Luíza. Nossos Feminismos Revisitados. In: RIBEIRO, Matinde. Dossiê Mulheres Negras. Revista Estudos Feministas, Florianópolis/SC, CFH/CCE/UFSC, v.3 n. 3, 1995.

BARBOSA, Magnair Santos. Cachoeira: ponto de confluência do Recôncavo Baiano. In: Festa da Boa Morte. Cadernos do IPAC,2. - Salvador: Fundação Pedro Calmon; 2010.

CARDOSO, Cláudia Pons. Outras falas: feminismos na perspectiva de mulheres negras brasileiras. 2012. 383f. - Tese (Doutorado) - Faculdade de Filosofia e Ciências Humanas. Universidade Federal da Bahia. Salvador, 2012. 
CHAUI, Marilena. Conformismo e resistência: aspectos da cultura popular no Brasil. São Paulo: Brasiliense, 1996.

COLLINS, Patricia Hill. Rasgos distintivos del pensamiento feminista negro. In: Jabardo, Mercedes (Org.). Feminismos Negros: una antologia. Madrid: Traficante de Suenos, 2012.

CONCEIÇÃO, Edjanara Mascarenhas. "Corre a roda mulher, corre a roda, o homem não sabe correr. Corre a roda mulher, corre a roda, a vida do homem é beber": identidades e performances de gênero nos grupos de samba de roda "Filhos do Paraguai/Segura Véia" e "Filhos de Dona Cadú". 2016. 124F. Dissertação (Mestrado em Ciências Sociais) - PPGCS. Universidade Federal do Recôncavo da Bahia, Cachoeira, 2016.

CRENSHAW, Kimberlé. Documento para o encontro de especialistas em aspectos da discriminação racial relativos ao gênero. Revista Estudos Feministas, v. 10, n. 1, p. 171188, 2002.

DINIZ, Flávia Cachineski. Capoeira Angola: identidade e trânsito musical. 2011. 274f. Dissertação (Mestrado em Etnomusicologia) - Escola de Música. Universidade Federal da Bahia, Salvador, 2011.

DÖRING, Katharina. Samba de Roda: visibilidade, consumo cultural e estética musical. Pontos de Interrogação, v. 3, n. 2, p. 147-174, jul./dez. 2013.

Cantador de chula: o samba antigo do recôncavo baiano. 1. ed.

Salvador, Pinaúna, 2016.

EVARISTO, Conceição. Histórias de leves enganos e parecenças. Rio de Janeiro: Malê, 2016.

FANON, Frantz. Pele negra, máscaras brancas. Trad. Renato da Silveira, Salvador:

Edufba, 2008.

FINNEGAN, Ruth. ¿Por qué estudiar la música? Reflexiones de una antropóloga desde el campo. Revista Transcultural de Música, Sociedad de Etnomusicología Barcelona, España, n.6, jun, 2002.

FREIRE, Rebeca Sobral. Hip Hop feminista?: convenções de gênero e feminismos no movimento hip hop soteropolitano. 2011. 171f. Dissertação (Mestrado) - PPGNEIM, Universidade Federal da Bahia, Salvador, 2011. 
FREITAS. Dalva. Samba Baiana: a vivência cantada de Dona Dalva. Direção: Any Manuela Freitas. Produção Executiva: Ana Olga Freitas e Martiniano Ferreira dos Santos. Cachoeira: Gravação Independente, 2011. 1 CD.

GIACOMINI, Sonia Maria. Mulher e escrava: uma introdução histórica ao estudo da mulher negra no Brasil. 2. ed. Curitiba: Appris, 2013.

GIROY, Paul. O Atlântico Negro: Modernidade e Dupla Consciência. São Paulo: Editora 34, Rio de Janeiro, 2001.

GOMES, Francimária R.; ROSA, Laila. Os processos de protagonismo de mulheres negras no Recôncavo da Bahia: o samba de roda como mediador das relações cotidianas. In: Seminário PPGCS, 5, 2015, Anais [...]. Cachoeira: UFRB, dez. 2015.

GOMES, Francimária Ribeiro. Trânsitos musicais e comunicação popular: experiências de protagonismo de mulheres negras em Cachoeira, BA. 2017. 159f. Dissertação (Mestrado) - PPGNEIM, Universidade Federal da Bahia, Salvador, 2017.

GOMES, R. C. S. A Casa do Samba, o Samba da Rua: relações de gênero, arte e tradição no samba carioca. In: NOGUEIRA I.P.; FONSECA, S. C. (Orgs.). Estudos de gênero, corpo e música: abordagens metodológicas. Goiânia/Porto Alegre: ANPPOM, 2013. p. 354-379. Série pesquisa em música no Brasil, v. 3.

GONZALEZ, Lélia. Racismo e sexismo na cultura brasileira. Revista Ciências Sociais Hoje. ANPOCS, p. 223-244, 1984.

A categoria político-cultural de amefricanidade. Tempo

Brasileiro, Rio de Janeiro, n. 92/93. p. 69-82, jan./jun., 1988.

GUERREIRO, Goli. Terceira diáspora. Culturas negras no mundo atlântico. Salvador: Corrupio, 2010.

GRAEFF, Nina. Os ritmos da roda: tradição e transformação do samba de roda. Salvador: EDUFBA, 2015.

HALL, Stuart. A identidade cultural na pós-modernidade. Rio de Janeiro: DP\&A, 1999. Da Diáspora: identidades e mediações culturais. Org. Liv Sovick. Trad. Adelaine La Guardia Resende et al. 1. ed. atual. Belo Horizonte: Editora UFMG, 2008. 
IPHAN. Dossiê de registro do Samba de Roda do Recôncavo Baiano. 2006. Disponível em: http://portal.iphan.gov.br/portal/baixaFcdAnexo.do?id=723 Acesso em 22 ago. 2014.

LÜHNING, Angela; ROSA, Laila. Música e cultura no Brasil. Da invisibilidade e "inaubilidade" à percepção dos sujeitos musicais. In: ALVES, Paulo César (org.). Cultura: múltiplas leituras. Bauru: EDUSC; Salvador: EDUFBA, 2010.

MARQUES, Francisca. Samba de Roda em Cachoeira, Bahia: uma abordagem etnomusicológica. 2003. 270f. Dissertação (Mestrado) - Escola de Música, Universidade Federal do Rio de Janeiro, Rio de Janeiro, 2003.

Festa da Boa Morte e Glória: ritual, música e performance.

2008. 318f. Tese (Doutorado) - Departamento de Antropologia Social, Universidade de São Paulo, São Paulo, 2008.

MARTÍN-BARBERO, Jesús. Dos meios às mediações. Comunicação, cultura e hegemonia. 6. ed. Rio de Janeiro: Editora UFRJ, 2009.

MISOCZKY, Maria Ceci. Análise crítica do discurso: uma apresentação. Revista Eletrônica de Gestão Organizacional. v. 3, n. 2, maio/ago. 2005. Disponível em http:// www.revista.ufpe.br/gestaoorg/index.php/gestao/article/viewFile/57/48. Acesso em 17 jan. 2016.

MOREIRA, Talitha Couto. Música, materialidade e relações de gênero: categorias transbordantes. 2012. 177f. Dissertação (Mestrado) - Escola de Música, Universidade Federal de Minas Gerais, Belo Horizonte, 2012.

Música, materialidade e relações de gênero: categorias transbordantes. In NOGUEIRA, I.P.; FONSECA, S.C. (Orgs.). Estudos de gênero, corpo e música: abordagens metodológicas. Goiânia, Porto Alegre, ANPPOM, 2013. p. 354-379.

NICHOLSON, Linda L. Hacia un método para comprender el genero. In:

ESCANDÓN,C.R. (org). Género e História. México: Instituto Mora, UAM, 1992.

NASCIMENTO, Luiz Cláudio Dias do. Bitedô: onde moram os nagôs: redes de sociabilidades africanas na formação do candomblé jêje-nagô no recôncavo baiano. Rio de Janeiro, CEAP, 2010.

NEPOMUCENO, Bebel. Protagonismo ignorado. In: PINSKY, C. B.; PEDRO, J. M. (Orgs.). Nova História das Mulheres no Brasil. São Paulo: Contexto, 2012. 
OLIVEIRA, Roberto Camargos de. Rap e política: percepções da vida social brasileira. 1.ed. São Paulo: Boitempo, 2015.

QUEIROZ, Clécia. A Estrela Dalva do samba de Cachoeira. In: SANTANA, Marilda (Org.) As bambas do samba: mulher e poder na roda. Salvador: EDUFBA, 2016.

PERUZZO, Cicilia M.K. Conceitos de comunicação popular, alternativa e comunitária revisitados. Reelaborações no setor. Palabra Clave, v. 11, n. 2, dic. 2008.

ROCHA, Décio; DEUSDARÁ, Bruno. Análise de Conteúdo e Análise do Discurso: aproximações e afastamentos na (re)construção de uma trajetória. Alea, Rio de Janeiro, v. 7, n. 2, p. 305-322. dez. 2005. Disponível em: http://www.scielo.br/scielo. php?pid=S1517-106X2005000200010\&script=sci_arttext.

RODRIGUES, Maria Natália Matias. Jovens mulheres rappers: reflexões sobre gênero e geração no movimento hip hop. 2013. 160f. Dissertação (Mestrado em Psicologia) Universidade Federal de Pernambuco, 2013.

SANTOS, Renata Conceição dos. Cantos de Trabalho: rupturas e permanências no Recôncavo sul da Bahia. In: ENCONTRO ESTADUAL DE HISTÓRIA: PODER, CULTURA E DIVERSIDADE, 3., 2007, Caetité. Anais [...]. Caetité: UNEB, Associação Nacional de História, Seção Bahia, 2007. Disponível em http://www.uesb.br/anpuhba/artigos/ anpuh_III/renata_conceicao.pdf. Acesso 13 jul. 2015.

SANTOS, Fernanda da C. dos. Documentação do Samba de Roda Suerdieck. 2010. 100f. Monografia (Graduação) - Centro de Artes, Humanidades e Letras, Universidade Federal do Recôncavo da Bahia, Cachoeira, 2010.

SANDRONI, Carlos. Feitiço decente: transformações do samba no Rio de Janeiro (1917-1933). Rio de Janeiro: Jorge Zahar; Ed. UFRJ, 2001.

SANTANA, Sandro. Música e ancestralidade na Quixabeira. Salvador: EDUFBA, 2012.

SEEGER, Anthony. Etnografia da música. Tradução Giovanni Cirino. Cadernos de Campo, São Paulo, n.17, p.1-24, 2008.

SILVA, Tomaz Tadeu da. A produção social da identidade e da diferença. In: SILVA, Tomas Tadeus da. (Org.). Identidade e diferença. Rio de Janeiro: Editora Vozes, 2000. p. 73-102. 
SOUSA, Mauro Wilton de. Recepção mediática: linguagem de pertencimento. Novos Olhares, Departamento de Cinema, Rádio e TV, Universidade de São Paulo, n. 3, p.1230, 1999.

WERNECK, Jurema Pinto. Nossos passos vêm de longe! Movimento de mulheres negras e estratégias políticas contra o sexismo e o racismo. Revista da ABPN, v. 1, n. 1, p. 1-11, mar./jun. 2010. Disponível em: http://www.abpn.org.br/Revista/index.php/ edicoes/ article/view/20/10. Acesso 22 mai. 2016. 